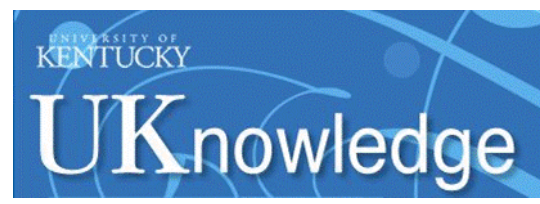

University of Kentucky

UKnowledge

Fall 2015

\title{
Revolution Demythologized
}

Jonathan Allison

University of Kentucky, jonathan.allison@uky.edu

Follow this and additional works at: https://uknowledge.uky.edu/english_facpub

Part of the English Language and Literature Commons

Right click to open a feedback form in a new tab to let us know how this document benefits you.

\section{Repository Citation}

Allison, Jonathan, "Revolution Demythologized" (2015). English Faculty Publications. 4.

https://uknowledge.uky.edu/english_facpub/4

This Book Review is brought to you for free and open access by the English at UKnowledge. It has been accepted for inclusion in English Faculty Publications by an authorized administrator of UKnowledge. For more information, please contact UKnowledge@lsv.uky.edu. 


\section{Revolution Demythologized}

\section{Notes/Citation Information}

Published in Sewanee Review, v. 123, no. 4, p. Ixi-Ixiv.

Copyright (@ 2015 The Johns Hopkins University Press. This article first appeared in Sewanee Review, Volume 123, Issue 4, Fall, 2015, pages Ixi-Ixiv. 


\section{CURRENT BOOKS IN REVIEW}

\section{REVOLUTION \\ DEMYTHOLOGIZED}

\section{Vivid Faces: The Revolutionary}

Generation in Ireland, 1890-1923

by Roy Foster

(Norton, 2015. 480 pages. $\$ 29.95$ )

Next year will witness the centenary celebrations in Ireland of the 1916 rebellion that would change the political and cultural landscape of Ireland forever, and which in effect led to the Sinn Fein electoral victory of 1918, the Anglo-Irish War of 1919-21, and the Irish Civil War that followed. For many people, the 1916 Easter Rising contains the origins of the modern Irish state which gained official status in 1937. The leaders of the Rising, sixteen of whom were executed by the British in the aftermath of the rebellion, became national heroes in the pantheon of Irish history. In the words of W. B. Yeats, they were "changed utterly" as they assisted in the birth of the "terrible beauty" of that Easter week.

There is a considerable literature on the revolutionary period in modern Ireland (1890-1923) and a large body of work on the cultural revival (which almost exactly coincides with that period). Vivid Faces: The Revolutionary Generation in Ireland, 1890-1923 by Roy Foster is a brilliant and original contribution to the study of the period, focused initially on the time before the rebellion, what Foster calls the "pre-revolution," with the aim of discovering what the rebels thought and felt they were doing. Few historians would take seriously Thomas Carlyle's notion of history as "the sum of innumerable biographies," but Foster's skill as a biographer has served him well in this fascinating account, which resembles in some ways a group biography. This is an extraordinary portrait of a generation, including the best-known figures of the period such as Patrick Pearse, Eamon De Valera, and Roger Casement, but also friends and family members of the major players. Foster draws from many contemporary sources, including personal correspondence and diaries, and he has mined the resources of the National Library of Ireland, the National Archives of Ireland (Dublin), the National Archives of Great Britain (Kew), the Military Archives of Ireland, the Archives of University College Dublin, Trinity College Dublin, and many other libraries. In so doing he has produced a vital record of the revolutionary period. The focus is on individuals and private lives, as well as on amatory relationships and friendships; as Foster writes, "the changes that convulse society do not appear from nowhere; they happen first in people's minds, and through the construction of a shared culture."

Widely regarded as one of the foremost Irish historians of his generation, Foster is the Carroll Professor of Irish History at Oxford University and is author of many books, including the standard history of the period, Modern Ireland 1600-1972; The Irish Story: Telling Tales and Making It Up in Ireland; and Paddy and Mr. Punch: Connections in Irish and English History. He has also written lives of Charles Stewart Parnell and Lord Randolph Churchill, as well as the magisterial two-volume life of Yeats: The Apprentice Mage 


\section{CURRENT BOOKS IN REVIEW}

and The Arch-Poet-a work which offers proof of Foster's talents as a biographer and literary critic as well as his authority as a historian of the late Victorian and modern periods. A brilliant political historian, he is also a major historian of culture and of the dynamic intersection (so vividly embodied in modern Ireland) between political and cultural change.

The title, Vivid Faces, is taken from Yeats's “Easter 1916," which opens with the declaration:

I have met them at close of day

Coming with vivid faces

From counter or desk among grey

Eighteenth-century houses.

These were the participants before they had been changed by the revolutionary events celebrated (and questioned) in the poem, which famously declares the rebels' hearts had been turned to stone by the sacrifice they and their nation had made. Yeats's friend Maud Gonne questioned this characterization at the time, claiming that political commitment does not turn you to stone, but makes you fully human. This debate is likely to continue in our present age of radicalization, but the texture and immediacy of the personal lives of the revolutionaries is decisively revealed in the course of Foster's study, which aims, in the author's words, to "strip back the layers of martyrology and posthumous rationalization."

As the historian F. S. L. Lyons wrote long ago, the Easter Rising seemed to cast a spell on a whole culture, which was persuaded to see 1916 as the turbulent, violent, and necessary event that was fons et origo of modern Ireland-a spell which made it difficult for historians and others who strained to give an objective and nuanced account of the period. Yeats himself contributed to the casting of this spell in his poetic account of the period between the death of Parnell in 1891 and the events of Easter week (what he called "a long gestation"), and yet even he introduced a note of skepticism in his question: "Was it needless death after all?" The spell led to simplistic hagiography of the participants, and the mythology of 1916 became a permanent part of the memory of the country, which in taking up arms became (in the words of the song) "a nation once again."

Foster's book is written with great narrative verve, with a lively, counterhagiographic tendency to point out the absurdities, pomposities, and petty jealousies of his subjects. For example, Patrick Pearse was "seen by many as erratic, unstable and (in Hobson's word) 'abnormal,"' and there are comic moments, as in this portrait of Thomas MacDonagh, fighting from his redoubt in Jacob's (biscuit) factory: "Sleep deprivation, isolation from other spheres of insurrectionary activity, and possibly the unrelieved diet of cake and biscuits made MacDonagh an erratic leader." And will Cesca Trench's reputation ever fully recover from this? "[So] ecstatic at the time of the Howth gun-running, and given to much self-congratulatory Anglophobic ranting, [she] found herself appalled at the carnage of the Rising." Shaped according to theme rather than strict chronology, the book is divided into nine chapters with quasi-novelistic titles such as "Loving," "Arming," "Reckoning," and "Remembering." 


\section{CURRENT BOOKS IN REVIEW}

In the opening chapter, "Fathers and Children," Foster proposes that this generation felt profound unease with the values of their predecessors: "Those who made the revolution knew they were different from their parents." Rebelling against the politics of John Redmond's Irish Parliamentary Party, which sought "Home Rule" by constitutional means, they pursued the ideal of independence by physical force. They were "alienated not only from British rule but from the values and ambitions of their parents." Foster's subjects are not only idealistic teachers, trades unionists, and agitating members of the working and lower-middle classes, they also include sons and daughters of the Catholic gentry, of the Presbyterian middle-class, and of the Anglo-Irish Ascendancy. Often rebelling against the bourgeois and upper-class values of comfortable and prosperous family backgrounds, they embraced socialism, feminism, nationalism, paramilitarism, and frequently married the kinds of radical nationalist intellectuals whom their parents would have deemed unsuitable.

In "Education" the author explores the role of formal education in shaping the political values of young people. Of course, family life plays a part in the shaping of character, but it is clear that Pearse's St. Enda's school for boys was singularly Republican in orientation, and no fewer than thirty combatants fighting in the rebel HQ in Dublin in 1916 were former pupils of that school. The legendary influence of the Christian Brothers is acknowledged, and Foster gives some credence to Todd Andrews's claim that "without the groundwork of the Christian Brothers' schooling it is improbable that there would ever have been a 1916 Rising."

In the chapter titled "Playing" the buildup to rebellion is set against the rich background of theaters and drama groups in the Ireland of the time, not only in Dublin but in many provincial centers like Cork and Belfast, where Bulmer Hobson ran the Ulster Literary Theatre. It is well known that Yeats and Lady Gregory's production of Cathleen ni Houlihan inspired audience members to a patriotic fervor, but the landscape of the "theatre of revolt" was wider and more varied than that. Drama was regarded as a highly politicized art form, capable of teaching moral and history lessons, and of awakening an audience to a heightened sense of the aspirations of the national community. Plays caused riots because people took drama seriously, and a surprising number of combatants in 1916 turned out to be amateur thespians, playwrights, and directors of folksy Hibernian plays. Indeed it was claimed there was a theatrical element to the Rising itself, and Foster observes that "more than one commentator would point to the choreographed nature of the event, as if the theatre had taken to the streets."

Beyond the theater, the cultural sphere was bristling with authors, journalists, and propagandists eagerly pursuing the dynamic connection between politics and the arts; writing was inevitably a politicized and engaged sphere. The chapter "Writing" explores with deftness the impact of literary culture more generally, from the radical bookshops like Tom Clarke's shop on 75A Great Britain Street, to anti-conscription pamphlets, to the radical journals 


\section{CURRENT BOOKS IN REVIEW}

evocatively titled Shan Van Vocht (Poor Old Woman of Ireland) and The United Irishman.

In "Loving" Foster observes that revolutionaries can sometimes be regarded as participants in a Freudian "Family Romance"-_a fantasy of reordering the family one inherits, replacing it with a new, liberated entity." He doesn't suggest this is uniformly true or applicable, and many did not seek unconventional affairs. A significant number, however, challenged the assumptions of their backgrounds and revolted against their Unionist or gentry backgrounds by "marrying out" (marrying out of, or beneath, or beyond their class or social backgrounds.) The Gifford sisters rejected their Unionist families in comfortable Rathmines to marry radical Catholic nationalists, and Mabel McConnell, daughter of a Presbyterian Belfast businessman, with firm links to the Orange Order, married the poet Desmond FitzGerald in a Roman Catholic ceremony before decamping to a bohemian, artistic life in Brittany. Their son Garret would later become Prime Minister (Taoiseach) of Ireland. In their personal lives, members of the revolutionary generation often had recourse to unconventional, scandalous, and sometimes illegal romantic and sexual adventures; and as Foster points out, many of the personal records he has read are candid about these matters, including the diaries of Rosamund Jacob, daughter of a Protestant family in Waterford, who writes explicitly about her romantic and sexual interests in this sphere. Foster is also very frank about Patrick Pearse's attraction to boys, to whom he wrote explicit erotic verses, and about Roger Casement's serial and persistent pedophilic cruising.

Many women in the revolutionary movement had associations with suffrage and feminist groups and had hopes that a new society would allow for greater autonomy, but part of the story he tells is how many people of this extraordinary generation were disappointed and even outraged by the conservative, Catholic, and church-controlled society which emerged after the civil war. Hence the final sentence in this book where he argues that the revolution these people made, "may not have been the revolution that they intended, or wanted." Indeed in the final chapter, "Remembering," Foster follows the fate of many of his subjects in old age. For the most part, the women are disappointed, bitter, and disillusioned-a word that recurs. This chapter considers the ways in which the revolution has been represented in historical memory and in particular how the Rising was seized on for official commemoration by the Irish state. (Better, and more astute, to commemorate the moment of unified rebellion than the divisive civil war which followed.) This set the scene for a hagiographic treatment of the rebels, which has hardly abated. Roy Foster has produced a masterly, brilliant account of those many individuals who have been celebrated, mythologized, and indeed "changed utterly" by the process of commemoration and retelling. Never before have they appeared so complex, nuanced, paradoxical, and fully human. 